\title{
MENINGKATKAN KEMAMPUAN SISWA MEMBACA ALQUR'AN DENGAN TARTIL DI KELAS 5-B SDN 050661 KW. BINGAI ME LALUI TEKNIK "BBM"
}

\author{
Khadijah \\ Surel: sugiono85@gmail.com
}

\begin{abstract}
ABSTRAK
Dari hasil penilaian yang dilaksanakan oleh guru pada saat kelas 5-B diketahui bahwa siswa memperleh nilai dibawah KKM lebih dari 50\%. Untuk mengatasi masalah ini dicoba mencari solusi untuk meningkatkan hasil belajar materi tajwid dengan menggunakan teknik "BBM" yaitu teknik pembelajaran yang menggunakan tiga tahapan proses yaitu Bermain, Berdiskusi dan Melantunkan. Proses pelaksanakan penelitian dilakukan selama dua siklus. Siklus 1 dan 2, masing-masing siklus terdiri dari 2 kali pertemuan. Pertemuan 1 melakukan tahap "Bermain" dan "Berdiskusi", sedangkan pertemuan 2 melakukan tahap "Melantunkan". Teknik "BBM" terbukti dapat meningkat kan hasil belajar siswa penguasaan konsep 87,5\% dan penerapan 87,5\%. $100 \%$ siswa menyatakan bahwa teknik "BBM" menyenangkan dan mampu membuat suasana kelas menjadi hidup dan menyenangkan sehingga siswa menjadi termotivasi Teknik "BBM" juga membawa manfaat positif terhadap kemampuan siswa mengungkapkan hasil pembelajaran melalui kata- kata dan berfikir kritis.
\end{abstract}

Kata Kunci : Cooperative Learning, Diskusi, Tajwid

\section{PENDAHULUAN}

Pendidikan dalam arti umum merupakan suatu aktivitas untuk mengembangkan seluruh aspek kepribadian manusia yang berlangsung seumur hidup sesuai dengan nilai-nilai yang ada di dalam masyarakat dan kebudayaan. Lebih spesifik pada pendidikan agama Islam disebutkan bahwa pendidikan Islam merupakan proses transformasi dan internalisasi ilmu pengetahuan dan nilai-nilai pada diri anak didik melalui pertumbuhan dan pengembangan potensi fitrahnya guna mencapai keselarasan dan kesempurnaan hidup dalam segala aspek metode juga memiliki kedudukan yang sangat signifikan dalam mencapai tujuan pendidikan Islam. Bahkan metode sebagai seni dalam mentransfer ilmu pengetahuan kepada siswa dianggap lebih signifikan daripada materi itu sendiri. Sebuah adagium mengatakan bahwa,"At Thariqatu ahammu minal maddah" (metode lebih penting di banding materi). Fakta mengatakan bahwa penyampaian materi dengan cara yang komunikatif lebih disukai 
oleh siswa, walaupun sebenarnya materi yang disampaikan tidak terlalu menarik. Sebaliknya, materi yang cukup menarik, karena disampaikan dengan cara yang kurang menarik, materi itu kurang dapat dicerna oleh siswa.

Guru sebagai pengelola pembelajaran berperan menciptakan iklim belajar yang memungkinkan siswa dapat belajar secara nyaman dan produktif. Melalui pengelolaan kelas yang baik guru dapat menjaga kelas agar tetap kondusif untuk terjadinya proses belajar siswa. Dalam hubungan dengan pengelolaan pembelajaran, pakar pendidikan menjelaskan beberapa prinsip belajar. Salah satu prinsip yang menjadi perhatian peneliti adalah "Apabila siswa diberi tanggung jawab, maka ia akan lebih termotivasi untuk belajar".

Tanggung jawab siswa dalam belajar sangat penting untuk diperhatikan guru karena tanggung jawab itu termasuk motivasi instrisik. Motivasi instrisik ini dapat dipertinggi dengan penggunaan materi yang menarik dan juga cara penyampaian materi pelajaran yang menarik pula. Beberapa pendekatan pembelajaran memiliki orientasi tertentu dengan tujuan akhirnya, seperti penyampaian materi menjadi menarik bagi siswa dan siswa mudah untuk belajar.

Selama ini, metodologi pembelajaran agama Islam yang diterapkan masih mempertahankan cara-cara lama (tradisional) seperti ceramah, menghafal dan demonstrasi praktik-praktik ibadah yang tampak gersang. Cara-cara seperti itu diakui atau tidak akan membuat siswa bosan, jenuh dan kurang bersemangat dalam belajar agama.

Jika siswa kurang tertarik dengan metode yang digunakan oleh guru, maka dengan sendirinya siswa akan memberikan umpan balik (feedback) yang kurang menyenangkan dalam proses pembelajaran, misalnya; siswa menjadi tidak simpati tehadap guru pelajaran, materi-materi pelajaran dan lama kelamaan bisa menimbulkan sikap acuh tak acuk terhadap pelajaran Agama Islam.

Oleh karena itu, penting sekali bagi guru Pendidikan Agama Islam menggunakan metode pembelajaran yang lebih kreatif dan inovatif, agar siswa dapat memberikan umpan balik yang positif sehingga akan meningkatkan minat, simpati dan keingintahuan yang mendalam terhadap mata pelajaran Pendidikan Agama Islam.

$\begin{array}{rrr}\text { Pengalaman } & \text { belajar } & \text { hanya } \\ \text { dapat diperoleh } & \text { jika } & \text { murid }\end{array}$ berpartisipasi secara aktif. Bentuk belajar secara aktif meliputi interaksi antara guru dengan murid, murid dengan murid lainnya, sekolah dengan rumah, sekolah dengan masyarakat dan siswa dengan segala macam alat serta media pembelajaran. Dengan demikian, siswa perlu didorong untuk senantiasa berpartisipasi aktif dalam 
pembelajaran sehingga pengalaman belajar yang mereka dapatkan juga semakin banyak.

Demikian pula pengalaman keagamaan hendaknya di pelajari murid melalui pengalaman yang aktual. Beberapa ketrampilan keagamaan dapat mereka pelajari melalui dramatisasi, bermain peran atau diskusi, misalnya: sembahyang, cara makan, cara bersopan santun, adab terhadap orangtua dan sebagainya. Sebagian lagi mungkin menghendaki ketrampilan menggunakan alat-alat dengan caracara tertentu, seperti misalnya pada peristiwa penyembelihan kurban, membagikan zakat fitrah dan sebagainya.

Untuk memberikan pengalaman belajar yang berarti bagi siswa, guru perlu menggunakan metode pembelajaran yang sesuai dengan karakteristik materi yang hendak diajarkan. Penggunaan metode yang tepat akan berpengaruh terhadap proses pembelajaran yang nantinya akan berpengaruh terhadap siswa dalam menyerap informasiinformasi dalam PBM.

Di lapangan ditemukan fakta bahwa pemahaman materi tajwid siswa SDN 050661 Kwala Bingai tergolong rendah. Hal itu bisa dilihat dari hasil penilaian yang dilaksanakan oleh guru pada saat kelas 5-B yang menyatakan bahwa siswa yang mendapat nilai di bawah Kriteria Ketuntasan Minimal) lebih dari 50\%. Dari hasil angket yang penulis sebar kepada 23 siswa juga didapatkan informasi bahwa hanya 15\% siswa yang senang terhadap materi tajwid dan 55\% menyatakan kadang-kadang memperhatikan apabila diajar materi tajwid. Hal ini disebabkan karena materi tajwid dianggap materi yang sulit, seperti pernyataan dari $73 \%$ siswa. Sedangkan untuk pelajaran PAI secara umum 60\% anak menyatakan senang dan $23 \%$ siswa menyatakan sangat senang.

Idealnya siswa bisa memperoleh nilai minimal sama dengan KKM, bahkan lebih dari itu. Apalagi target klasikal pembelajaran PAI untuk materi tajwid adalah $85 \%$ siswa bisa memperoleh nilai sama dengan atau lebih dari KKM (75). Namun kenyataan yang terjadi jauh dari harapan dan kondisi ideal. Padahal, ilmu tajwid merupakan ilmu yang digunakan untuk membaca $\mathrm{Al}$ Qur'an dengan benar. Berarti ilmu juga merupakan ilmu yang harus dikuasai oleh seorang muslim. Ilmu tajwid tidak hanya dipelajari di sekolah formal, namun di TPQ dan juga TPA ilmu ini diajarkan. Dengan demikian, ilmu tajwid sudah bukan hal yang asing lagi bagi siswa.

Berdasarkan rumusan masalah di atas, tujuan yang ingin dicapai dan penelitian ini adalah: 1) Mendiskripsikan proses peningkatan kemampuan membaca al-qur'an secara tartil siswa kelas 5-B SDN $050661 \mathrm{Kw}$. Bingai melalui teknik BBM pada tahun pelajaran 2017/2018, 2) Mendiskripsikan hasil 
peningkatan kemampuan membaca al-qur'an secara tartil siswa kelas 5-B SDN $050661 \mathrm{Kw}$. Bingai melalui teknik BBM pada tahun pelajaran 2017/2018.

Sasaran penelitian adalah adanya peningkatan nilai penguasaan konsep maupun penerapan hukum tajwid dari yang awalnya lebih dari $50 \%$ siswa tidak bisa memenuhi KKM menjadi $85 \%$ siswa mencapai bahkan melampaui KKM. Adapun KKM yang ditetapkan adalah 75 untuk penguasaan konsep dan 75 untuk penerapan.

\section{METODE PENELITIAN}

Penelitian ini dilakukan di SD Negeri 050661 KW. Bingai. Adapun yang menjadi subjek dalam penelitian ini ialah siswa kelas 5-B SD Negeri 050661 KW. Bingai. Penelitian ini dilakukan untuk bertujuan meningkatkan kemampuan siswa kelas 5-B membaca alqur'an pada mata pelajaran Agama Islam melalui teknik BBM.

Teknik "BBM" merupakan teknik pembelajaran yang menggunakan tiga tahapan proses yaitu Bermain, Berdiskusi dan Melantunkan. Penelitian ini merupakan Penelitian Tindakan Kelas. Proses pelaksanakan penelitian dilakukan selama dua siklus. Siklus 1 dan 2 , masing-masing siklus terdiri dari 2 kali pertemuan. Pertemuan 1 melakukan tahap "Bermain" dan "Berdiskusi", sedangkan pertemuan 2 melakukan tahap "Melantunkan". Teknik pengumpulan data dalam penelitian ini menggunakan observasi (pengamatan), angket dan test.

\section{HASIL DAN PEMBAHASAN}

Sebelum diterapkan teknik "BBM", penulis mengadakan pre test tentang hukum bacaan Qolqolah dan Ra' untuk membaca alqur'an secara tartil yang akan dibahas dalam penelitian. Begitu pula setelah selesai tindakan, penulis memberikan postes yang soalnya sama dengan pre test. Berikut ini penulis tampilkan hasil pre test dari 23 siswa yang ada di kelas 5-B dapat dilhat dari grafik $1 \mathrm{di}$ bawah ini:

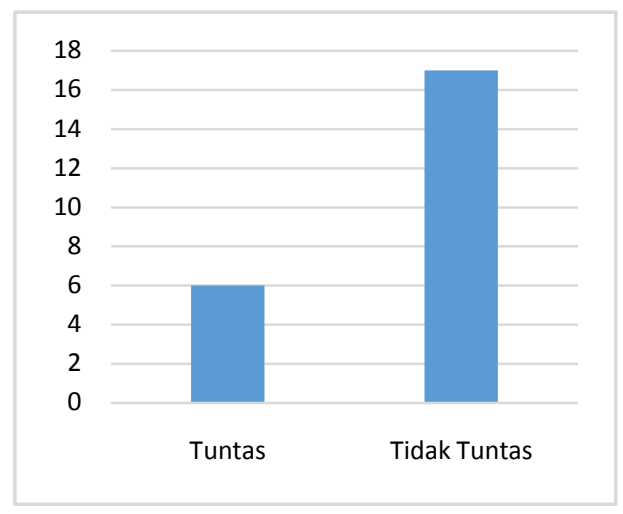

\section{Gambar 1. Penguasaan Konsep Siklus I}

Dari gambar di atas, menunjukkan bahwa dari 23 siswa, sebanyak 6 siswa $(26,09 \%)$ tuntas dalam pembelajaran, sedangkan 17 siswa $(73,91 \%)$ tuntas dalam pembelajaran materit adwid pada materi hukum Qolqolah utnuk membaca Al-Qur'an secara tartil. Persentase pencapaian rata- rata siswa pada pretest siklus pertama adalah 53,04 .

Hasil di atas belumlah memenuhi target mata pelajaran PAI pada penelitian ini. Oleh karena itu, 
penulis rasa perlu adanya penelitian pada siklus kedua. Hal itu bisa dimaklumi karena masing-masing siswa mempunyai tingkat pemahaman yang berbeda. Di samping itu, masing-masing siswa mempunyai gaya belajar yang berbeda. Akan tetapi, penulis telah melakukan tindakan korektif terhadap metode pada siklus kedua sehingga hasil belajar bisa meningkat.

Benyamin S. Bloom
berpendapat bahwa tingkat keberhasilan (penguasaan dapat dicapai, kalau pengajaran yang di berikan secara klasikal bermutu baik dan berbagai tindakan korektif terhadap siswa yang mengalami kesulitan dilakukan dengan cepat (Martinis Yamin, 2007).

Pada siklus kedua, untuk melihat sejauh mana penguasaan konsep siswa, diperoleh hasil tes sebagai berikut:

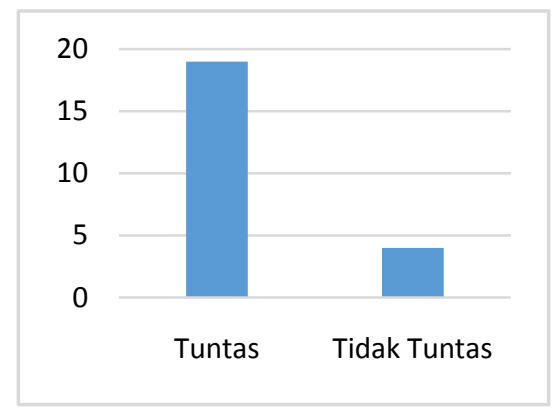

Gambar 2. Penguasaan Konsep Siklus II

Data di atas menunjukkan bahwa hasil belajar siswa pada siklus kedua mengalami peningkatan. Sebanyak siswa $(82,61 \%)$ mengalami ketuntasan dalam pembelajaran materi tajwid materi hukum Ro' untuk pembacaan alqur'an secara tartil, sedangkan sisanya yang 4 siswa $(17,39 \%)$ masih belum tuntas walaupun hasil tes menunjukkan adanya peningkatan.

Penelitian ini penulis anggap cukup karena target pembelajaran PAI yang diinginkan adalah sebanyak $85 \%$ atau lebih dari jumlah siswa mengalami ketuntasan dalam pembelajaran.

Untuk mengetahui kemampuan siswa pada penerapan materi tajwid dalam membaca $\mathrm{Al}$ Qur'an, maka peneliti melakukan tes kemampuan penerapan materi Qolqolah dan Ro' dalam membaca Al Qur'an dengan diberi surat yang sama baik pada pretest maupun posttest. Adapun surat tersebut, penulis ambil dari surat yang ada dalam papan permainan. Untuk kepentingan ini, penulis paparkan hasil pre-test dan post test siklus pertama dan kedua.

Di bawah ini disajikan data hasil belajar aspek penerapan siswa pada siklus pertama.

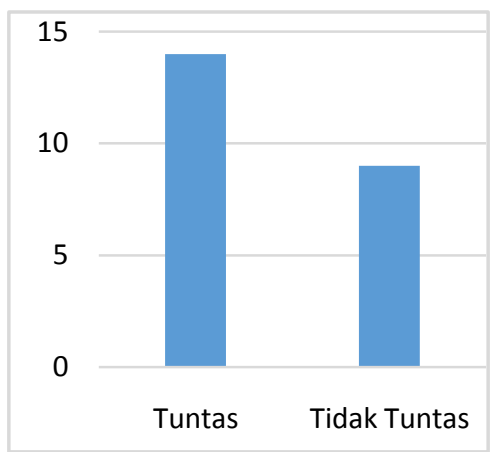

Gambar. 3 Hasil Pembelajaran Pada Aspek Penerapan Siklus I 
Dari 23 siswa yang mengalami ketuntasan hasil belajar pada aspek penerapan adalah 14 siswa $(60,87 \%)$. Sedangkan 9 orang siswa $(39,13 \%)$ dinyatakan tidak berhasil dalam pembelajaran materi Qolqolah dalam membaca Al-Qur'an secara tartil. Persentase pencapaian pada aspek penerapan siklus pertama adalah 73,69. Hasil di atas belumlah memenuhi target mata pelajaran PAI pada penelitian ini. Oleh karena itu, penulis rasa perlu adanya penelitian pada siklus kedua.

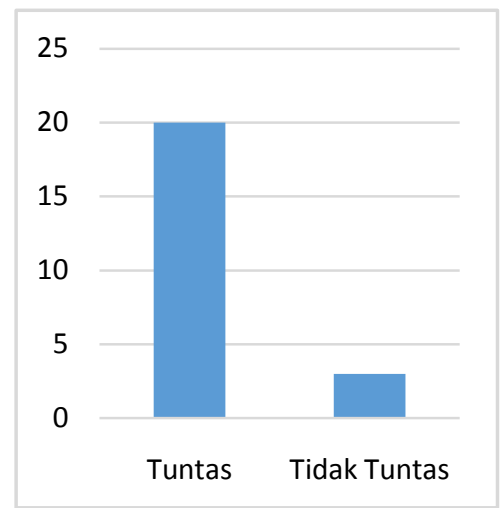

Gambar 4. Hasil Pembel ajaran Pada Aspek Penerapan Siklus II.

Hasil belajar siswa kelas 5-B pada aspek penerapan siklus kedua sebanyak 20 siswa $(87,0 \%)$ mengalami keberhasilan dalam belajar, sedangkan sisanya 3 siswa $(13,0 \%)$ mengalami kegagalan atau tidak tuntas.

Sedangkan persentase pencapaian aspek penerapan siswa pada siklus kedua pada aspek penerapan adalah 79,3. Dari hasil tersebut, penelitian ini sudah cukup karena sudah mencapai target pencapaian pada mata pelajaran PAI yaitu $85 \%$.

\section{Pembahasan}

Sebenarnya, pembelajaran Pendidikan Agama Islam tidak hanya menekankan pada penguasaan konsep dan nilai-nilai. Yang lebih penting dari itu adalah penerapan nilai-nilai dalam kehidupan sehari-hari sehingga Pelajaran PAI baru dikatakan berhasil apabila terjadi perubahan sikap pada diri peserta didik yang didasari dari kesadaran diri yang tinggi. Dengan adanya perubahan sikap pada peserta didik, diharapkan akan semakin meningkatkan keimanan dan ketaqwaan peserta didik kepada Tuhan Yang Maha Esa. Tujuan pengajaran Agama Islam menurut Dr. Zakiyah Daradjat dkk. (1983) adalah supaya orang mempunyai pengetahuan tentang ajaran Islam untuk diyakini dan diamalkan sehingga ia menjadi seorang muslim dan selanjutnya berkepribadian muslim. Hal ini sejalan dengan tujuan pendidikan Nasional yang akan membentuk manusia Pancasila yang bertakwa kepada Tuhan Yang Maha Esa.

Apakah pembelajaran PAI selama ini sudah memenuhi harapan tersebut? Sebuah fakta yang tidak bisa dipungkiri bahwa selama ini, peserta didik menganggap bahwa pelajaran PAI merupakan pelajaran yang tidak menarik dan membosankan. Hal itu mungkin dikarenakan materi PAI kebanyakan 
berupa nilai, moral dan norma-norma yang bersifat abstrak dan dogmatis. Esensi dari materi PAI tersebut mengakibatkan guru PAI merasa bahwa metode penyampaian yang paling tepat untuk pelajaran PAI adalah metode ceramah.

Kenyataan di atas merupakan sebuah tantangan dari guru PAI untuk bisa menampilkan Pelajaran PAI sebagai sebuah pembelajaran yang menarik dan menyenangkan agar tujuan pengajaran Agama Islam dapat tercapai. Karena, bagaimana mungkin nilai- nilai yang terkandung dalam PAI tersebut akan diamalkan apabila pelajaran itu sendiri dianggap tidak menyenangkan dan membosankan oleh peserta didik?

Penggunaan metode yang tepat akan turut menentukan efektifitas dan efisiensi pembelajaran, serta membantu peserta didik dalam mencapai tujuan pembelajaran. Pengalaman belajar di sekolah harus fleksibel dan tidak kaku, serta perlu menekankan ada kreatifitas, rasa ingin tahu, bimbingan dan pengarahan ke arah kedewasaan.

Dr. E. Mulyasa, M.Pd (2005) mengatakan bahwa kreatifitas peserta didik sangat tergantung pada kreatifitas guru dalam mengembangkan materi stándar, dan menciptakan lingkungan belajar yang kondusif. Guru dapat mengadakan berbagai pendekatan dalam meningkatkan kreatifitas peserta didik.
Dari hasil observasi dan perolehan angket yang penulis sebar, dapat ditarik kesimpulan bahwa siswa kelas 5-B SDN No $050661 \mathrm{Kw}$. Bingai membutuhkan metode yang lebih tepat untuk memahami materi tajwid agar dapat meningkatkan hasil belajar siswa.

Dalam melakukan proses belajar mengajar, guru harus menggunakan metode yang bervariasi dan tidak monoton dengan menggunakan satu metode saja. Dengan menggunakan metode yang bervariasi, siswa akan merasa termotivasi dan senang mengikuti kegiatan pembelajaran. Disamping itu, metode yang digunakan juga harus dapat meningkatkan keaktifan siswa di kelas.

Teknik "BBM" diterapkan oleh peneliti dengan sebuah pendekatan yang tidak membatasi ruang gerak peserta didik dalam pembelajaran dan mengembangkan kreatifitas peserta didik untuk mendapatkan pengetahuanpengetahuan baru. Teknik ini juga membantu mengembangkan rasa percaya diri peserta didik dengan membantu mereka mengembangkan kesadaran dirinya secara positif tanpa menggurui dan mendikte mereka.

Setelah penulis laksanakan teknik ini dalam materi tajwid selama dua siklus, penulis dapat menyimpulkan bahwa penting sekali bagi guru untuk mengetahui kecenderungan gaya belajar siswa. Dengan mengetahui kecenderungan 
gaya belajar, guru akan dapat menentukan metode dan media apa yang tepat digunakan dalam proses pembelajaran sesuai dengan karakteristik materi pelajaran. Apabila metode dan media pembelajaran sudah tepat, maka siswa akan lebih mudah dan cepat menyerap sebuah informasi.

Teknik "BBM" terbukti bisa menfasilitasi siswa belajar dengan gaya belajar yang berbeda (visual, auditorial dan kinestetik). Tahapantahapan pada teknik "BBM" juga memberikan kesempatan kepada siswa untuk berkembang sesuai dengan kecerdasan berganda yang dimiliki oleh masing-masing siswa.

\section{SIMPULAN}

Dari hasil penelitian di atas dapat di simpulkan bahwa:

1. Penggunakan tehnik pembelajaran BBM mampu meningkatkan hasil belajar dalam kemampuan membaca alqur'an secara tartil siswa kelas 5-B Tahun pembelajaran 2017/2018.

2. Hasil siklus I dengan hasil siklus II pada penguasan konsep terjadi peningkatan $26,09 \%$ ketuntasan menjadi $82,61 \%$ ketuntasan pada siklus II.

3. Hasil siklus I dengan hasil siklus II pada aspek peerapan terjadi peningkatan $60,87 \%$ ketuntasan menjadi $87,0 \%$ ketuntasan pada siklus II.

\section{DAFTAR RUJUKAN}

Arikunto, Suharsimi. 2002. Penelitian Tindakan Kelas. Jakarta: PT Bumi Aksara.

Depdiknas. $2008 . \quad$ Strategi Pembelajaran dan Pemilihannya. Direktorat Jendral Peningkatan Mutu Pendidikan dan Tenaga Kependidikan, Departemen Pendidikan Nasional.

Deporter, Bobbi, dkk. 2000. Quantum Teaching Memraktekkan Quantum Learning di Ruang-ruang Kelas. Bandung: Mizan Media Utama.

Ghony, M. Djunaidi. 2008. Penelitian Tindakan Kelas. Malang: UIN Perss.

Mulyasa. E, 2005. Menjadi Guru Profesional. Bandung: Remaja Rosdakarya.

Muslih, Masnur. 2007. KTSP Pembelajaran Berbasis Kompetensi dan Kontekstual. Jakarta: Bumi Aksara.

Sanjaya, Wina. 2008. Kurikulum dan Pembelajaran. Jakarta: Kencana Predana Media Group. 